\title{
Implementation of STEM-based Student Worksheet to Increase Student Entrepreneurial Innovation through the Development of Candied Nutmeg Products
}

\author{
Dara Sasmita ${ }^{*}$, Muhammad Adlim¹, Abdul Gani ${ }^{1}$, Muhammad Syukri ${ }^{1}$ \\ ${ }^{1}$ Program Studi Pendidikan IPA PPs Universitas Syiah Kuala, Banda Aceh, Indonesia
}

DOI: $10.29303 /$ ippipa.v7i1.551

\section{Article Info}

Received: December $12^{\text {th }}, 2020$

Revised: January 20th, 2021

Accepted: January 29th, 2021

\begin{abstract}
The research has been carried out to develop STEM-based Student Worksheets to determine their effectiveness in increasing students' entrepreneurial innovation through the development of candied nutmeg products and the responses of teachers and students to the Student Worksheet. The research was conducted using the research and development ( $\mathrm{R} \&$ D) method using the ADDIE model. The sample in this study were 34 students of class XI IPA 1, selected using a random sampling technique. The research data were obtained from expert assessment sheets, Student Worksheets, and questionnaires for teachers and students. The results of the STEM-based Student Worksheet feasibility test by the experts showed that the Student Worksheet developed was classified as very worthy, with an average percentage value of $94.17 \%$. The percentage of Yes responses obtained from teachers and students was $100.00 \%$ and $92.06 \%$ in the very good category. Based on the results of the study, it can be concluded that the developed STEM-based Student Worksheet can increase students' entrepreneurial innovation and can be used as alternative teaching material in craft and entrepreneurship materials, and get positive responses from teachers and students.
\end{abstract}

Keywords: Student Worksheet; STEM; innovation

Citation: Sasmita, D., Adlim, M., Gani, A., \& Syukri, M. (2021). Implementation of STEM-based Student Worksheet to Increase Student Entrepreneurial Innovation through the Development of Candied Nutmeg Products. Jurnal Penelitian Pendidikan IPA, 7(1), 112-120. doi:https://doi.org/10.29303/jppipa.v7i1.551

\section{Introduction}

The 2013 curriculum provides changes to the subject sector by incorporating craftsmanship and entrepreneurship into new subjects for grade X SMA students (Pamungkas and Sutrisno, 2014). Craft and entrepreneurship subjects aim to foster an entrepreneurial spirit from an early age and to prepare for the birth of entrepreneurship (Purbaningrum, 2016). The failure of education to produce alumni who are ready to use and who have entrepreneurial spirit will have an impact on the high unemployment rate (Hutasuhut, 2013). Data from the Central Statistics Agency shows that around $7.37 \%$ of people still do not have jobs (Central Statistics Agency, 2019). Lack of creativity and skills is one of the contributing factors. Therefore, students must have the creativity and be brave in entrepreneurship (Aprilianty, 2012).
The results of case studies and interviews that have been conducted at SMAN 3 Banda Aceh show that students are less active in the learning process of craftsmanship and entrepreneurship. This is due to the lack of teaching materials in the form of student worksheets which can support the activeness of students in the process of teaching and learning activities. Student Worksheet is one of the learning media (Nugraheny, 2018). Student Worksheet is used as teaching material to direct students in learning. Student Worksheet is also used as a guide so that students can carry out active and independent learning activities (Novelia, et al., 2017).

Student Worksheet can be combined with a learning approach. The approach that fits the requirements of the 2013 curriculum is the STEM approach (Ramli, et al., 2020). STEM is a learning 
approach that can create a fun and independent learning atmosphere.

The STEM approach is not just memorizing concepts, but rather understanding scientific concepts and their relation to everyday life. Learning that is associated with the environment so that a fun learning process can be realized for students (Herak, 2019). STEM is an approach to four components of science, namely: knowledge, technology, engineering, and mathematics (Khoiriyah, et al., 2018). STEM can solve the problems of students by combining science, technology, and mathematics (Rahmiza, et al., 2015). Therefore, STEM-based learning is suitable for application in the teaching and learning process.

Nutmeg (Myristica Fragrans Hoult) is a native Indonesian plant originating from the Banda and Maluku islands which then spread and developed to various islands including Aceh, North Sulawesi, and Papua (Atmaja, et al., 2017). Nutmeg is also a spice that has high economic value (Kamelia and Silalahi, 2018). The price of nutmeg is very affordable, besides that, it has many health benefits. In Aceh, nutmeg seeds are often added to food as a spice, while the pulp is used as sweets. Candied nutmeg, which is known to the people of Aceh, only has a sweet taste of sugar, so many are less interested in consuming it. Even if innovated, candied nutmeg can have a high selling value and can attract consumers to buy it. Based on the background of the problem, the researcher is interested in conducting a study with the title "Application of STEM-based Student Worksheet to Increase Student Entrepreneurial Innovation through the Development of Candied Nutmeg Products".

\section{Method}

Research data collection was carried out at SMAN 3 Banda Aceh in the odd semester of the 2020/2021 academic year from 8 to 27 November 2020 . The research was conducted using this type of research and development research method, which aims to produce a product in the form of a Student Worksheet. The development model used is ADDIE which includes the following steps: (1) analysis, (2) design, (3) development, (4) implementation, and (5) evaluation.

The stages of the ADDIE development model are (1) Analysis, which consists of analyzing the needs of teaching materials and analyzing the character and condition of students. (2) Design, making Student Worksheet designs based on analysis that has been carried out on a STEM basis and according to the criteria of a good Student Worksheet preparation; (3) Development, conducts a development process to realize a Student Worksheet design that is in accordance with the needs of the learning process. Then, validation by experts on the physical and content of the Student Worksheet. Based on the results of the validation, the Student Worksheet was revised and then implemented in schools; (4) Implementation, the results of the Student Worksheet products obtained were given to students to work on, then questionnaires were distributed to teachers and students to see their responses to the Student Worksheet; (5) Evaluation, evaluating Student Worksheet to see the success of Student Worksheet. The evaluation was carried out in the form of giving scores to the Student Worksheet, determining the impact of learning, and analyzing the responses of teachers and students to the STEM-based Student Worksheet that had been developed.

The instruments used were the needs analysis sheet, the Student Worksheet product quality assessment sheet, the observation sheet for the improvement of students' innovation abilities, a questionnaire sheet, and an assessment sheet for the appearance and taste of the product that had been validated by experts in their fields.

The population in this study were students of class XI SMAN 3 Banda Aceh. The sample in this study was 34 class XI IPA1 students, selected using a random sampling technique which was determined based on the advice of the chemistry teacher at SMAN 3 Banda Aceh.

The data obtained during the next study were analyzed. The percentage $(\mathrm{P})$ of the validity of the Student Worksheet, the increase in the innovation ability of students, is calculated using the following formula (Usman \& Akbar, 2006).

$$
\mathrm{P}=\frac{\text { Gotten score }}{\text { Ideal score }} \times 100 \%
$$

To provide an assessment score can be seen in Table 1.

Table 1. Student Worksheet Feasibility Assessment Criteria

\begin{tabular}{lll}
\hline No & $\begin{array}{l}\text { Student Worksheet } \\
\text { Eligibility (\%) }\end{array}$ & Category \\
\hline 1 & $81-100$ & Very Worth it \\
2 & $61-80$ & Well worth it \\
3 & $41-60$ & Decent enough \\
4 & $21-40$ & Not worth it \\
5 & $0-20$ & Not feasible \\
\hline
\end{tabular}

(Source: Arikunto, 2013)

Then, the percentage of teacher and student responses is calculated using the following formula (Trianto, 2009).

$$
\mathrm{P}=\frac{\text { Sum of choosen by respondent }}{\text { Total respondent }} \times 100 \%
$$

The criteria for describing the responses of teachers and students can be presented in Table 2 . 
Table 2. Description of the Response Values of Teachers and Students

\begin{tabular}{lll}
\hline No & Response Score (\%) & Category \\
\hline 1 & $86-100$ & Very good \\
2 & $76-85$ & Good \\
3 & $60-75$ & Enough \\
4 & $55-59$ & Less \\
5 & $0-54$ & Very less \\
\hline
\end{tabular}

(Source: Purwanto, 2004)

Furthermore, the data obtained from the assessment of the candied nutmeg food product were calculated using the following formula.

$$
\text { Score }=\frac{\text { Total gotten score }}{\text { Total ideal score }} \times 4 \%
$$

The description criteria are presented in Table 3.

Table 3. Description of the Product Score of Candied Nutmeg Foods

\begin{tabular}{lll}
\hline No & Response Score (\%) & Category \\
\hline 1 & $3.66-4.00$ & Very good \\
2 & $2.66-3.65$ & Good \\
3 & $1.66-2.65$ & Enough \\
4 & $1.00-1.65$ & Less \\
\hline
\end{tabular}

(Source: Ministry of Education and Culture, 2014)

\section{Results and Discussion}

\section{Development of STEM-based Student Worksheet}

The development of the STEM-based Student Worksheet aims to determine the ability of students to innovate in craft and entrepreneurship materials. The method used in this research is research and development (R\&D) with the ADDIE model. The description of each ADDIE stage carried out by researchers in the development of the Student Worksheet is as follows:

\section{Analysis}

At this stage, an analysis of literature studies and field studies are carried out by digging up information about the teaching and learning process that has been carried out so far at SMAN 3 Banda Aceh. In addition, an analysis of the availability of teaching materials in schools was also carried out. Researchers conducted a needs analysis by providing a questionnaire containing questions in terms of the learning process and teaching materials. The results of the needs analysis are as follows:

\section{a. Learning Process}

Teachers rarely use teaching materials and still use the lecture method when students make certain products in the learning process.

b. Teaching Materials

Teaching materials that are often used by teachers are only in the form of textbooks available in schools so that it does not improve the innovation abilities of students. So it takes a teaching material that is able to foster student innovation.

The results of the needs analysis show that the handcrafted and entrepreneurial learning that is carried out in science classrooms has not yet linked science, teachers also rarely use Student Worksheet. Basically, the Student Worksheet is very important to determine the success of students in absorbing and mastering the knowledge that has been given (Widodo, 2017). Teachers need teaching material in the form of a Student Worksheet that can be used in science learning. The application of STEM is suitable for use in science learning (Permanasari, 2016). The ability of students in the fields of science and mathematics can be improved through the application of STEM (Mu'minah and Aripin, 2019). Therefore, researchers developed a teaching material in the form of a STEM-based Student Worksheet which is suitable for use in science learning and can foster students' innovation.

\section{Design}

Student Worksheet design is designed in such a way and is based on STEM. Student Worksheet consists of six main elements, namely the title, study instructions, basic competencies or subject matter, supporting information, assignments or work steps, and assessment (Directorate of Senior High School Development, 2010). In this Student Worksheet design, there are several components in the form of cover, competence and objectives, instructions for use, learning materials and supporting information, as well as tasks/work steps that students must do. The components are described as follows: 1) Cover is the front page of the Student Worksheet which contains the title of the Student Worksheet and the identity of the student. This section also contains pictures related to candied nutmeg. 2) Competencies and learning objectives contain the competencies and goals to be achieved by students. 3) Instructions for use contain how to use Student Worksheet to make it easier for students to learn. This section also shows the STEM components and more details can be seen in Table 4 .

Table 4. Concepts Related to STEM Components

\begin{tabular}{ll}
\hline $\begin{array}{l}\text { STEM } \\
\text { Components }\end{array}$ & Related Concepts \\
\hline Science & $\begin{array}{l}\text { Knowledge of the benefits of the candied } \\
\text { nutmeg ingredients } \\
\text { Technology }\end{array}$ \\
$\begin{array}{l}\text { Making product packaging (in the form of } \\
\text { stickers) candied nutmeg using technology } \\
\text { such as computers } \\
\text { Technique and processing of candied } \\
\text { nutmeg, as well as selecting the } \\
\text { appropriate ingredients for candied } \\
\text { nutmeg food products } \\
\text { Calculations are required in calculating the } \\
\text { mathematics }\end{array}$ \\
\hline
\end{tabular}


a. Learning materials and supporting information contain information about the knowledge of nutmeg which is presented in step I. Observation.

b. Tasks steps that students must do. Students are asked to follow step II. New Ideas, processing nutmeg, and generating new ideas about candied nutmeg innovations. Step III. Innovation (Innovation), innovating processed nutmeg sweets. Step IV. Creativity, making packaging stickers for candied nutmeg products has been innovated. The final step V. Society calculates the approximate selling price of candied nutmeg.

The design results obtained are submitted to the experts to be asked for suggestions so that the Student Worksheet that has been designed is better. The initial design of the Student Worksheet is presented in Figure 1.

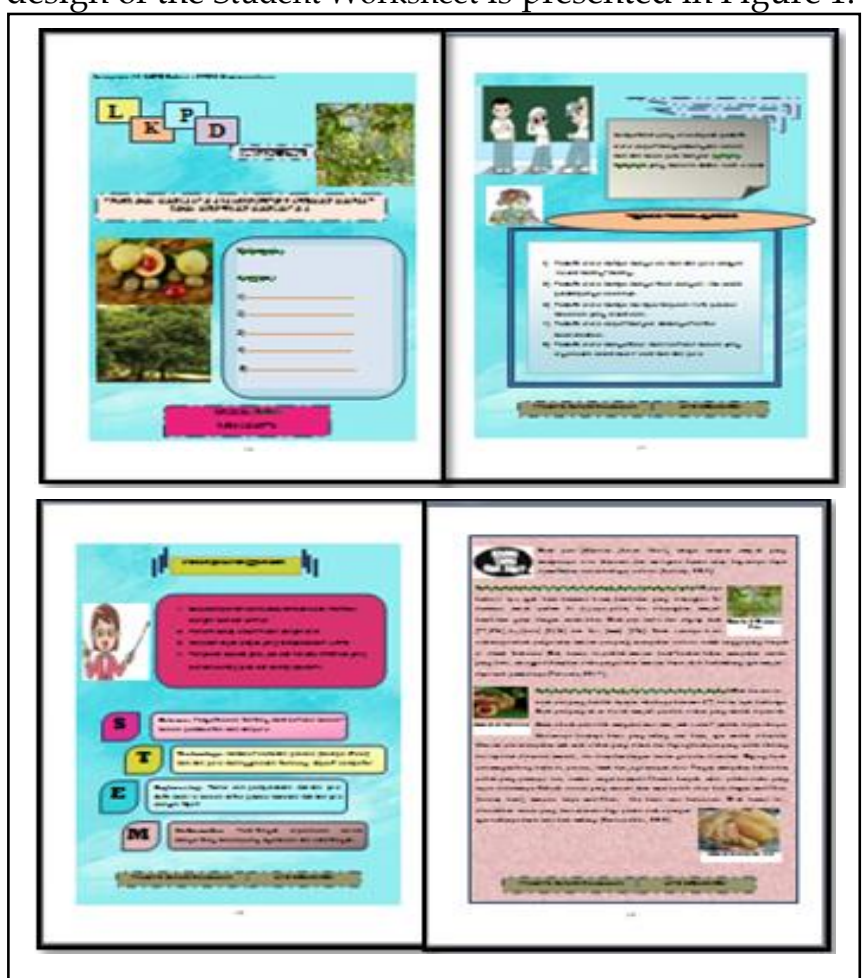

Figure 1. Initial Design of STEM-based Worksheet

\section{Development}

At this stage, validation is carried out by expert validators of the STEM-based Student Worksheet that has been developed. Student Worksheet quality assessment is based in terms of material, learning components, presentation, language, physical, illustrations in pictures, and completeness. The validation instrument was adapted and modified from the National Education Standards Agency (BSNP) and adapted to the characteristics of the Student Worksheet developed by the researcher. The validation results obtained in the form of suggestions and improvements for each component of the Student Worksheet are presented in Table 5.
Table 5. Validator Suggestions Against Student Worksheet

\begin{tabular}{ll}
\hline Validator & \multicolumn{1}{c}{ Suggestion } \\
\hline I & Replace the image on the cover with an \\
innovative product image from candied nutmeg \\
- Make sure every step of Engineering Science \\
Engineering (EST) is clearly and systematically \\
listed on the Student Worksheet \\
- Change the command sentence in the science \\
section (the benefits of the ingredients used), the \\
II \\
word from should not be put at the beginning of \\
- Arrange the question sentence in the \\
engineering section into a more effective \\
sentence, changing the question mark into an \\
exclamation point in the second sentence \\
- Put a period after the abbreviation of the name \\
of the author of the article in journal taken in \\
the bibliography \\
- Adjust the color of the writing with the Student \\
Worksheet background \\
- Display the table in the science section to make \\
it easier for students to write down the benefits \\
of the materials used \\
- Create command sentences in the science \\
section (the preservative nutmeg used) so that \\
students understand the author's intent
\end{tabular}

The results of the revised Student Worksheet based on suggestions from the validator can be seen more clearly in Figure 2.
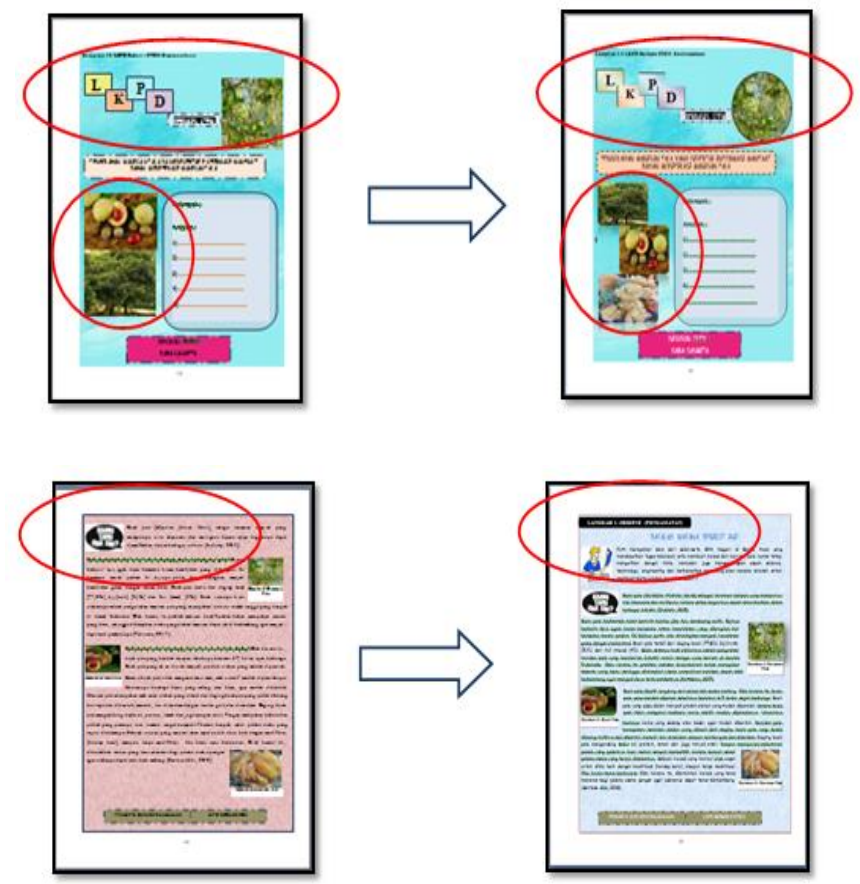

Figure 2. Design Revision Results

Student Worksheet products that have been assessed for quality by experts for more details can be 
seen in Appendix A5. The results of the validation by each validator can be seen in Table 6 .

Table 6. Results of Student Worksheet Validation and Research Instruments

\begin{tabular}{llll}
\hline No & Validator & Rating Score (\%) & Criteria \\
\hline 1 & I & 95.00 & Very Worth it \\
2 & II & 92.50 & Very Worth it \\
3 & III & 95.00 & Very Worth it \\
Average & 94.17 & Very Worth it \\
\hline
\end{tabular}

The average value obtained indicates that the feasibility value of the Student Worksheet is in the very feasible criteria with an average value of $94.17 \%$. This is consistent with the research conducted by Simatupang, et al. (2019) that the average percentage of feasibility for developing STEM-based Student Worksheet is $94.64 \%$ with the very feasible category. This is also in line with the Student Worksheet feasibility score described by Arikunto (2013) which states that the $81-100 \%$ value range for the Student Worksheet feasibility assessment is in the very feasible category. Based on the results obtained from the validator, the STEM-based Student Worksheet that has been developed can be used at the trial stage.

\section{Implementation}

At this stage, the Student Worksheet that has been validated by experts is then implemented to students. The implementation was carried out at SMAN 3 Banda Aceh. Student Worksheet was implemented in class XI Science 1, totaling 34 students. Researchers looked at activities during implementation in general, namely: (1) the researcher distributed STEM-based Student Worksheet to each group, (2) Students processed the nutmeg into candied nutmeg, (3) Innovated the candied nutmeg that had been made and made packaging stickers, (4) asked for an assessment of the nutmeg candy innovation made, (5) presented the results of their work.

Students are asked to solve various problems, from processing the nutmeg into sweets, innovating the candied nutmeg that has been made, designing and designing candied nutmeg packaging stickers, and being able to calculate the estimated selling price of candied nutmeg. All of these things are expected so that students gain knowledge and can develop their innovation and creativity. STEM learning has been shown to increase the creativity of students (Fathoni, et al., 2020).

\section{Evaluation}

Based on the development model used, this is the final stage in the development process. This stage is carried out to evaluate the entire series of teaching and learning processes that have been carried out and provide value to STEM-based Student Worksheet. Evaluation is carried out by analyzing the responses of teachers and students to the developed STEM-based Student Worksheet. The responses of teachers and students will be explained as follows:

a. Teachers' responses to STEM-based Student Worksheet

Teachers' responses to the STEM-based Student Worksheet that have been developed were obtained by distributing questionnaires to 6 teachers who teach craftsmanship and entrepreneurship at SMAN 3 Banda Aceh. The questionnaire given contains 10 questions with indicators that include Student Worksheet material as an alternative to craft material, the suitability of Student Worksheet with learning objectives and STEM components, ease of understanding the discussion, systematic writing, completeness of instructions for use, display of Student Worksheet, ease of being taught to students, the interest of readers, and conformity with the abilities of students.

Based on the 10 questions given, the percentage value is $100 \%$, included in the very good category. This shows that the teacher agrees that learning using STEM-based Student Worksheet can be an alternative material for craftsmanship and entrepreneurship because the materials and projects provided at the Student Worksheet can increase the innovation and creativity of students, and students gain knowledge that can be applied to entrepreneurship, by the objectives of learning. This is in accordance with the statement of Hanif, et al. (2019) stated that STEM project-based learning can be used as an alternative teaching strategy. In addition, the Student Worksheet also includes work steps to innovate candied nutmeg which includes STEM field skills. Very good responses can also be seen in the material presented in the STEMbased Student Worksheet, all teachers answered that the material presented was systematic and the language used was easy to understand.

The manual for using Student Worksheet is also considered complete because it includes all components that can make it easier for students to learn it. In addition, the Student Worksheet appearance is already attractive because the images are shown and the color combinations used are appropriate. This is in accordance with the statement of Purnamasari, et al. (2020) that Student Worksheet draws compatibility between text and images, and also uses colors that are not striking. All teachers also think that the use of the Student Worksheet can increase students' interest in learning because it can encourage curiosity and make students more active in learning. The next response given by the teacher was related to the content of the Student Worksheet, namely the discussion on the content of the Student Worksheet was easy to understand so that 
it was in accordance with the abilities of students. With the ease of understanding the material contained in the Student Worksheet, students can easily do all the exercises given (Diani, et al., 2019).

Based on the description above, it can be seen that the teacher's response to the STEM-based Student Worksheet was developed very well. Therefore, this Student Worksheet is feasible and can be used as an alternative material for craftsmanship and entrepreneurship.

\section{b. Student responses to STEM-based Student Worksheet}

The response of students to the STEM-based Student Worksheet that has been developed is known by giving a questionnaire to 34 students. The percentage of students' responses who chose the Yes option was $92.06 \%$ and included in the very good category. This shows that almost all students gave a positive response to the STEM-based Student Worksheet that was developed. This is by the research of Sulistiyowati, et al. (2018) that the results of student questionnaire responses after using the developed STEM-based Student Worksheet were $92.73 \%$ in the very good category. The results of other studies indicate that the students' responses to the developed Student Worksheet obtained an average score of $95.80 \%$ are in the very good category, so it can be concluded that the Student Worksheet given is good for use (Silvia and Simatupang, 2020).

\section{Student Innovation Assessment}

The assessment of students' innovation is based on food products produced by students through activities in their groups. Assessment is carried out before and after students innovate the material to be innovated. Three aspects are measured, the first aspect is the expected changes, namely students identify the results of the innovations that have been made. The second aspect is the expected changes, here students are required to explain the impact of innovative products on consumers. The last aspect that is measured is evaluating the results that have been obtained, students assess the risks and benefits of innovation. The assessment is determined by selecting the answer options using a range of 1 to 4 . The food product innovated by students is in the form of candied nutmeg. The innovation is made in the form of modification of the taste and shape of the incisions in the nutmeg. The results of the observation sheet recapitulation of students' innovation abilities can be seen in Table 7.
Table 7. Assessment of Students' Innovation Ability

\begin{tabular}{lllc}
\hline No & $\begin{array}{l}\text { Innovation Capability } \\
\text { Assessment }\end{array}$ & Before & After \\
\hline 1 & $\begin{array}{l}\text { Identify the results of } \\
\text { innovation }\end{array}$ & 0 & 90.44 \\
2 & $\begin{array}{l}\text { Describe the impact of } \\
\text { innovative products on } \\
\text { consumers }\end{array}$ & 0 & 86.76 \\
3 & $\begin{array}{l}\text { Assess the risks and benefits } \\
\text { of innovation }\end{array}$ & 0 & 82.35 \\
Average & 0 & 86.52 \\
\hline
\end{tabular}

Table 7 shows that the students' innovation ability increased from $0 \%$ to $86.52 \%$, including in the very good category. This is because students follow the steps in STEM-based Student Worksheet which are developed in innovating to increase the knowledge of students in innovating a product. This is in accordance with the opinion expressed by Utami, et al. (2017) that STEM-based learning can improve the ability of students in science and innovate in technology products so they can compete globally. This is also supported by the statement of Zokowski, et al. (2016) that STEM-based learning can make students creative and innovative and they gain knowledge that can be applied to entrepreneurship.

\section{Innovative products of candied nutmeg produced during the implementation of STEM-based Student Worksheet \\ The innovated candied nutmegs were then} assessed by the teachers using the product assessment sheets that had been prepared. The range of scales used for the assessment is 1 to 4 . The aspects assessed are the physical, creativity, and taste of the products produced by students. The results of the product assessment are presented in Table 8.

Table 8. Assessment Results of Candied Nutmeg Innovation

\begin{tabular}{lllllll}
\hline Rated & \multicolumn{2}{l}{ Group Score } & & & & \\
\cline { 2 - 7 } Aspect & & I & II & III & IV & V \\
\hline Manisan & Physical & 3.67 & 3.17 & 3.83 & 3.67 & 3.67 \\
Nutmeg & form & & & & & \\
Innovation & Creative & 3.67 & 3.50 & 3.67 & 3.67 & 3.33 \\
Average & Taste & 3.50 & 3.33 & 3.33 & 3.00 & 3.50 \\
\hline
\end{tabular}

Table 8 shows that the results of the assessment of the candied nutmeg innovation that were made by each group obtained an average value of $3.61 ; 3.33 ; 3.61$; 3.44 and 3.50 and included in the good category. These results show that learning using a STEM-based Student Worksheet can produce students who have skills in innovating a product. In addition, STEM has a good influence on the creativity of students (Hanif, et al., 2019). 
The innovation value of candied nutmeg made by groups I, III, and V were higher than the values obtained by groups II and IV. This shows that groups I, III, and V are doing their assigned tasks seriously. Healthy competition can have a good influence on the success of the learning process of students. Through competition, students can try earnestly to get the best results (Manizar, 2015). Candied nutmeg innovations made by students were in the form of candied red nutmeg, candied nutmeg for snow princess, candied nutmeg salad, sweetest candied nutmeg, and candied nutmeg jelly. The results of the candied nutmeg innovation that have been made are presented in Figure 3.
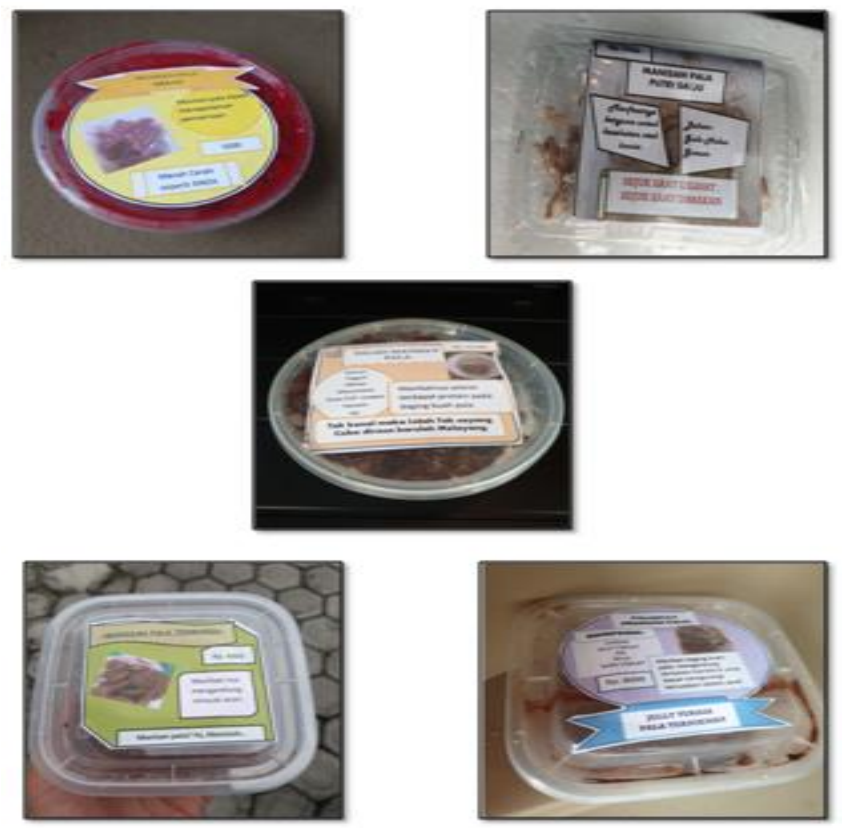

Figure 3. Innovative Results of Candied Nutmeg

\section{Conclusion}

Based on the results of the study, it can be concluded that the STEM-based Student Worksheet to increase the entrepreneurial innovation of the education students through the development of candied nutmeg products developed is classified as very feasible and usable. The entrepreneurial innovation ability of students in the application of STEM-based Student Worksheet is very good, namely $86.52 \%$. The responses of students and teachers to the developed STEM-based Student Worksheet showed a positive response with a percentage of $100.00 \%$ and $92.06 \%$ including the very good category.

\section{References}

Aprilianty, E. (2012). Pengaruh kepribadian wirausaha, pengetahuan kewirausahaan, dan lingkungan terhadap minat berwirausaha siswa SMK. Jurnal Pendidikan Vokasi, 2(3): 311-324. doi: https://doi.org/10.21831/jpv.v2i3.1039

Arikunto. (2013). Prosedur Penelitian Suatu Pendekatan Praktik Edisi Revisi. Jakarta: PT. Rineka Cipta.

Atmaja, T.H.W., Mudatsir., \& Samingan. (2017). Pengaruh Konsentrasi Ekstrak Etanol Buah Pala (Myristica fragrans) Terhadap Daya Hambat Staphylococcus aureus. Jurnal EduBio Tropika, 5(1):1-53. Retrieved from: http://jurnal.unsyiah.ac.id/JET/article/view/7 $\underline{139}$

Central Statistics Agency. (2019). Tingkat Pengangguran Terbuka (TPT) sebesar 5,01 persen, (online), (https://www.bps.go.id., diakses 6 Mei 2019).

Diani, D.R., Nurhayati, \& Suhendi, D. (2019). Pengembangan Lembar Kerja Peserta Didik (LKPD) Menulis Cerpen Berbasis Aplikasi Android. Jurnal Bahasa, Sastra, dan Pengajarannya, 7(2):

1-13. doi: https:// doi.org/10.20961/basastra.v7i2.3780 $\underline{0}$

Directorate of Senior High School Development. (2010). Juknis Pengembangan Bahan Ajar Edisi Revisi. Jakarta: Ditjen Dikdasmen.

Fathoni, A., Muslim, S., Ismayati, E., Rijanto, T., Munoto, \& Nurlaela, L. (2020). STEM: Inovasi dalam Pembelajaran Vokasi. Jurnal Pendidikan Teknologi dan Kejuruan, 17(1): 33-42. doi: http://dx.doi.org/10.23887/jptkundiksha.v17i1.22832

Hanif, S., Wijaya, A.F.C., \& Winarno, N. (2019). Enhancing Students' Creativity through STEM Project-Based Learning. Journal of Science Learning, 2(2): 50-57. doi: https:// doi.org/10.17509/jsl.v2i2.13271

Herak, R \& Lamanepa, G.H. (2019). Meningkatkan kreativitas siswa melalui STEM dalam pembelajaran IPA. Jurnal EduMatSains, 4(1):89-98. doi: https:// doi.org/10.33541/edumatsains.v4i1. $\underline{1047}$

Hutasuhut, S. (2013). Revitalisasi Pendidikan Kewirausahaan untuk Meningkatkan Daya Saing Ekonomi. Jurnal Pendidikan Ekonomi dan Bisnis, 5(3): 159-169.

Kamelia, L.P.L., \& Silalahi, P.Y. (2018). Buah Pala Sebagai Salah Satu Fitofarmaka yang menjanjikan di Masa depan. Molucca Medica, 11(1):96-101.

doi: https:/ / doi.org/10.30598/molmed.2018.v11. i1.96

Ministry of Education and Culture. (2014). Peraturan Menteri Pendidikan dan Kebudayaan Republik 
Indonesia Nomor 104 Tahun 2014 Tentang Penilaian Hasil Belajar oleh Pendidik pada Pendidikan Dasar dan Pendidikan Menengah. Jakarta: Kemendikbud.

Khoiriyah, N., Abdurrahman, dan Wahyudi, I. (2018). Implementasi pendekatan pembelajaran STEM untuk meningkatkan kemampuan berpikir kritis siswa SMA pada materi gelombang bunyi. JRKPF UAD, 5(2):53-62. doi: http://dx.doi.org/10.12928/jrkpf.v5i2.9977

Manizar, E. (2017). Peran Guru Sebagai Motivator Dalam Belajar. Tadrib, 1(2), 204-222. Retrieved from

http://jurnal.radenfatah.ac.id/index.php/Tadri b/article/view/1047

Mu'minah, L.H., \& Aripin, I. (2019). Implementasi Pembelajaran IPA Berbasis STEM Berbantuan ICT untuk Meningkatkan Keterampilan Abad 21. Jurnal Sainsmat, 8(2): 28-35. doi: https://doi.org/10.35580/sainsmat82107172 $\underline{019}$

Novelia, R., Rahimah, D., \& Fachruddin S,M. (2017). Penerapan Model Mastery Learning Berbantuan LKPD Untuk Meningkatkan Hasil Belajar Matematika Peserta Didik Di Kelas VIII.3 SMP Negeri 4 Kota Bengkulu. Jurnal Penelitian Pembelajaran Matematika Sekolah, 1(1): 20-25. doi: https://doi.org/10.33369/ip2ms.1.1.20-25

Nugraheny, D.C. (2018). Penerapan Lembar Kerja Peserta Didik (LKPD) Berbasis Life Skills untuk Meningkatkan Keterampilan Proses dan Sikap Ilmiah. Jurnal Visipena 9(1): 194-1114.

Pamungkas, C., \& Sutrisno, B. (2014). Pelaksanaan Pembelajaran Prakarya dan Kewirausahaan dengan Kurikulum 2013. Jurnal Pendidikan Ilmu Sosial, 24(2): 1-15. doi: 10.2317/jpis.v24i2.655

Permanasari, A. (2016). STEM Education: Inovasi dalam Pembelajaran Sains. Prosiding Seminar Nasional Pendidikan sains, di Surakarta 22 Oktober 2016.

Purbaningrum, C.W.D. (2016). Pengembangan Model Pembelajaran Prakarya \& Kewirausahaan dengan Prinsip The Great Young Enterpreneur di SMK untuk Kurikulum 2013. Jurnal Pendidikan Vokasi, 6(1): 15-23. doi: https:// doi.org/10.21831/jpv.v6i1.8112

Purnamasari, A., Karoma, Bukhori, K.A., \& Sairi, A.P. 2020. Analisis Persepsi Peserta Didik terhadap Lembar Kerja Peserta Didik Pembelajaran Fisika SMA Negeri 8 Palembang. Jurnal Ilmu Fisika dan Pembelajarannya, 4(1): 6-15. Retrieved from http://jurnal.radenfatah.ac.id/index.php/jifp/a rticle/view/5568

Purwanto, N., \& Surjaman, T. (2004). Prinsip-Prinsip dan Teknik Evaluasi Pengajaran. Bandung: Remaja Rosdakarya.
Rahmiza M.S., Adlim, \& Mursal. (2015). Pengembangan Lks STEM (Science, Technology, Engineering, And Mathematics) dalam Meningkatkan Motivasi dan Aktivitas Belajar Siswa Sma Negeri 1 Beutong Pada Materi Induksi Elektromagnetik. Jurnal Pendidikan Sains Indonesia, 3(1):239-250. Retrieved from http://jurnal.unsyiah.ac.id/JPSI/article/view/7 $\underline{670}$

Ramli, R., Yohandri., Sari, Y.S., \& Selisne, M. (2020). Pengembangan Lembar Kerja Peserta Didik Fisika Berbasis Pendekatan Science, Technology, Engineering, and Mathematics untuk Meningkatkan Berfikir Kritis Peserta Didik. Jurnal Eksata Pendidikan, 4(1): 10-17. doi: https:// doi.org/10.24036/jep/vol4-iss1/405

Silvia, A., \& Simatupang, H. (2020). Pengembangan LKPD Berbasis Science, Technology, engineering, and Mathematics untuk Menumbuhkan Keterampilan Literasi Sains Peserta Didik Kelas $X$ MIA SMA Negeri 14. BEST Journal (Biology Education, Sains and Technology). doi: https:// doi.org/10.30743/ best.v3i1.2434

Simatupang, H., Sianturi, A., \& Alwardah, M.N. (2019). Pengembangan LKPD Berbasis Pendekatan Science, Technology, Engineering, and Mathematics (STEM) untuk Menumbuhkan Keterampilan Berfikir Kritis Siswa. Jurnal Pelita Pendidikan, 7(4): 170-177. doi: https://doi.org/10.24114/ipp.v7i4.16727

Sulistiyowati., Abdurrahman., \& Jalmo, T. (2018). The Effect of STEM-Based Worksheet on Students' Science Literacy. Tadris: Journal of Education and Teacher Training, 3(1): 89-96. doi: https://doi.org/10.24042/tadris.v3i1.2141

Trianto. (2009). Mendesain Model Pembelajaran InovatifProgresif. Jakarta: Kencana.

Usman, H., \& Akbar, P.S. (2006). Pengantar Statistika. Jakarta: Bumi Aksara.

Utami, I.S., Septiyanto, R.F., Wibowo, F.C., \& Suryana, A. (2017). Pengembangan STEM-A (science, technology, engineering, mathematic and animation) Berbasis Kearifan Lokal dalam Pembelajaran Fisika. Jurnal Ilmiah Pendidikan Fisika Al-BiRuNi, 66(1): 67-73. doi: https://doi.org/10.24042/jpifalbiruni.v6i1.1 $\underline{581}$

Widodo, S. (2017). Pengembangan Lembar Kegiatan Peserta Didik (LKPD) Berbasis Pendekatan Saintifik untuk Meningkatkan Keterampilan Penyelesaian Masalah Lingkungan Sekitar Peserta Didik di Sekolah Dasar. Jurnal Pendidikan Ilmu Sosial, 26(2): 189-204.

Zokowski, P., Geramita, K., Ashdown, J., Brooks, B., \& Thompkins, A. (2016). Connecting Kids to STEM 
Trough Entrepreneurship and Innovation.

Prosiding disajikan pada IEEE Integrated STEM

Education Conference, Princeton University, di

New Jersey, 5 Maret 2016.

doi:10.1109/ISECON.2016.7457557 